\title{
Pemberdayaan Peran Kader Sebagai Penyuluh Menggunakan Kartu Edukasi IUFD Modifikasi Dwi Maryanti (IUFD MoBiDiti Card) Sebagai Antisipasi Kematian Janin Dalam Rahim Di Kelurahan Sidanegara Cilacap Tengah Tahun 2020
}

\author{
Dwi Maryanti ${ }^{1}$, Trimeilia Suprihatiningsih ${ }^{2}$, Mika Tri Kumala Swandari ${ }^{3}$ \\ ${ }^{1}$ Prodi D3 Kebidanan STIKES Al-Irsyad Al-Islamiyyah Cilacap \\ ${ }^{2}$ Prodi Ners STIKES Al-Irsyad Al-Islamiyyah Cilacap \\ ${ }^{3}$ Prodi S1 Farmasi STIKES Al-Irsyad Al-Islamiyyah Cilacap \\ Email korespondensi : bidandwimaryanti@gmail.com.
}

\begin{abstract}
Abstrak
Kematian janin dalam rahim (KJDR) berdasarkan riset penulis menunjukan bahwa kejadian Berat Badan Lahir Rendah (BBLR) memberikan risiko sebesar 101,36 kali untuk mengalami KJDR. Faktor yang berkontribusi terhadap berat badan lahir rendah yaitu kondisi anemia selama hamil, keadaan Kurang Energi Kronis (KEK). Kejadian KEK dan anemia di Puskesmas Cilacap Tengah 1 diketahui sepanjang tahun 2018 dan 2019. Wilayah kecamatan Cilacap Tengah I mencakup 5 kelurahan, salah satunya kelurahan Sidanegara. Kelurahan Sidanegara terdapat terdapat 23 RW dan pada setiap RW terdapat perwakilan 1 ketua kader. Luaran : IUFD MoBiDiti Card, HKI Karya Cipta dan Publikasi Ilmiah. Tujuan dari pengabdian ini adalh meningkatkan pengetahuan dan keterampilan kader KIA tentang KJDR dengan menggunakan IUFD MoBiDiti Card sebagai antisipasi KJDR. Metode pelaksanaan dilakukan melalui kegiatan promosi dan preventif. Kegiatan pengabdian masyarakat meliputi apersepsi, pengisian pre tes dan post tes serta pemberian materi KJDR dengan IUFD MoBiDiti Card. Pretes dan post tes berisi materi KJDR dan diberikan kepada sasaran yaitu kader KIA. Hasil pengabdian menunjukkan terjadi peningkatan pengetahuan berdasarkan rata-rata pre test dan post tes. Nilai rata-rata pre test 58 dan post test 73. Kesimpulan : IUFD MoBiDiti Card dapat meningkatkan pengetahuan Kader KIA tentang KJDR.
\end{abstract}

Kata kunci : KJDR, IUFD MoBiDiti Card, Kader KIA

\begin{abstract}
According to the author's research about Intra Uterine Fetal Death (IUFD) shows that Low Birth Weight (LBW) gives a risk of 101.36 times for experiencing IUFD.. Factors that contribute to LBW are anemia during pregnancy, Chronic Energy Deficiency (KEK). The incidence of KEK and anemia at the Cilacap Tengah 1 Public Health Services was known throughout 2018 and 2019. Central Cilacap I sub distric includes 5 urban village, one of them is Sidanegara village. In Sidanegara village there are $23 R W$ and in each $R W$ there is a representative of 1 cadre leader. Output: IUFD MoBiDiti Card, Intelectual Property Rights (IPR) and publication. The aim of community services activities is to increase the knowledge and skills of KIA cadres about IUFD by using the IUFD MoBiDiti Card to anticipate IUFD. The method of implementation is through promotional and preventive activities. Community service activities include apperception, filling in the pre-test and post-test as well as providing IUFD material with the IUFD MoBiDiti Card. The pretest and posttest contained IUFD material and were given to the target, namely KIA cadres. The results show that there is an increase in knowledge based on the average pre-test and post-test. The mean score of pre-test is 58 and post-test is 73. Conclusion: IUFD MoBiDiti Card can increase the knowledge of KIA cadres about KJDR.
\end{abstract}

Keyword: IUFD, IUFD MoBiDiti Card, KIA Cadre

Jurnal Pengabdian Masyarakat Al-Irsyad Vol. II, No. 2. Oktober 2020 


\section{PENDAHULUAN}

Kematian janin dalam rahim (KJDR) atau Intra Uterine Fetal Death (IUFD) adalah keadaan kematian yang terjadi pada janin dengan batasan usia kehamilan 20 minggu keatas atau berat badan janin 500 gram atau lebih (Maryanti, 2019). Terdapat beberapa faktor yang mempengaruhi terjadinya KJDR, diantaranya tercantum dari beberapa hasil riset yaitu usia ibu yang masuk dalam golongan berisiko adalah berusia dibawah 20 tahun dan diatas usia 35 tahun, golongan paritas primipara dan grandemultipara, ibu yang mengalami penyulit selama kehamilan serta keadaan anemia pada masa hamil (Sofia semian, Yani Widyastuti, \& Dyah Noviawati Setya Arum, 2018; Triana, 2012).

Penulis pada tahun 2019, telah melakukan penelitian untuk mengkaji faktor maternal dan neonatal pada responden yang mengalami KJDR, dimana pada tahun 2017 dan 2018 di RSUD Cilacap masing-masing sejumlah $48(2 \%)$ dan 43 (1,8\%) dari seluruh persalinan. Hasil penelitian menunjukkan bahwa berat badan lahir yang kurang dari normal memberikan risiko sebesar 101,36 kali untuk mengalami KJDR. Sedangkan, faktor masa gestasi yang kurang dari 37 minggu atau lebih dari 42 minggu berisiko sebesar 3,57 untuk menjadi KJDR serta riwayat penyakit memberikan peluang sebesar 4,46 kali (Maryanti, 2019).

Berat badan lahir menjadi faktor paling berisiko pada penelitian diatas, hal ini merujuk pada bahwasannya terdapat beberapa faktor yang berkontribusi terhadap berat badan lahir rendah yaitu kondisi anemia selama hamil, keadaan kurang energi kronis (KEK), jarak antar kehamilan yang kurang dari 2 tahun, kenaikan berat badan selama hamil dan adanya penyakit penyerta selama hamil (Cynthia, PH, Fatimah, SP, Rahfiludin, 2017; Fajriana, A, Buanasita, 2018; Marlenywati, Hariyadi, Didik, Ichtiyati, 2015; Sulistyorinim D, Siswoyo, 2014).

Diketahui pada periode Januari - Agustus 2019 terdapat 72 ibu hamil dengan anemia dan pada periode tahun 2018 terdapat $120 \mathrm{ibu}$ hamil dengan anemia dan $61 \mathrm{ibu}$ hamil dengan kurang energi protein (KEK). Dari 72 ibu hamil dengan anemia pada tahun 2019 diketahui mayoritas ibu hamil tidak berisiko, multigravida, trimester III dan tidak KEK (Septiyaningsih, Indratmoko, \& Yunadi, 2019).

Berdasarkan beberapa penelitian diatas dapat ditarik benang merah bahwa faktor risiko paling besar dari KJDR adalah berat badan lahir. Faktor yang berpengaruh pada berat badan lahir antara lain keadaan anemia dan KEK. Di Puskesmas Cilacap Tengah 1 diketahui sepanjang tahun 2018 dan 2019 terdapat ibu hamil dengan KEK dan anemia.

Berdasarkan latar belakang diatas maka, penulis melalui lembaga penelitian dan pengabdian kepada masyarakat STIKES Al Irysad Al Islamiyyah Cilacap bermaksud 
mengadakan pengabdian kepada masyakat yang berjudul Pemberdayaan Peran Kader Sebagai Penyuluh Menggunakan Kartu Edukasi Dwi Maryanti IUFD Card (IUFD MoBiDiti Card) Sebagai Antisipasi Kematian Janin Dalam Rahim Di Kelurahan Sidanegara Cilacap Tengah Tahun 2020. Diketahui di Cilacap Tengah I mencakup 5 kelurahan, salah satunya kelurahan Sidanegara. Di Kelurahan Sidanegara terdapat terdapat 24 RW dan pada setiap RW terdapat perwakilan 1 ketua kader. Setiap bulan selalu ada pertemuan kader di aula kelurahan Sidanegara untuk meningkatkan pengetahuan kader agar bisa diteruskan ke ibu hamil maupun ibu balita pada saat posyandu.

Besar harapan penulis melalui kegiatan pengabdian kepada kader, maka kader dapat melakukan penyuluhan tentang antisipasi KJDR dengan IUFD MoBiDiti Card kepada ibu hamil yang datang ke posyandu. Dengan penyluhan ini, diharapkan ibu hamil dapat meminimalisir risiko kejadian KJDR dengan pengetahuan yang didapat.

\section{MASALAH}

Berdasarkan latar belakang diatas, dapat dirumuskan masalah bahwa : Pada periode Januari - Agustus 2019 di Puskesmas Cilacap Utara I terdapat 72 ibu hamil dengan anemia dan pada periode tahun 2018 terdapat 120 ibu hamil dengan anemia dan 61 ibu hamil dengan kurang energi protein (KEK) Dari 72 ibu hamil dengan anemia pada tahun 2019 diketahui mayoritas ibu hamil tidak berisiko, multigravida, trimester III dan tidak KEK. Dengan demikian, langkah awal diperlukan suatu solusi untuk menjangkau ibu hamil agar terhindar dari KJDR, melalui sasaran kader untuk dapat memberikan edukasi kepada ibu hamil yang datang ke posyandu.

\section{METODE}

Metode yang digunakan dengan memberikan pelatihan untuk meningkatkan pengetahuan dan ketrampilan kader mengenai antisipasi kematian janin dalam rahim menggunakan kartu edukasi IUFD modifikasi Dwi Maryanti (IUFD MOBIDITI CARD) adalah sebagai berikut :

1) Ceramah

Metode ceramah dipilih untuk teori dan konsep yang akan dilakukan agar peserta (kader) dapat menguasai materi. Materi yang disampaikan berupa pengetahuan kematian janin dalam rahim dengan menggunakan kartu edukasi IUFD modifikasi Dwi Maryanti (IUFD 
MOBIDITI CARD). Ceramah untuk meningkatkan pengetahuan kader ini diharapkan mampu meningkatkan peran kader dalam mengantisipasi kematian janin dalam rahim.

2) Demonstrasi

Tim pelaksana memberikan contoh (mendemonstrasikan) cara penggunaan kartu edukasi IUFD modifikasi Dwi Maryanti (IUFD MOBIDITI CARD).

3) Pendampingan

Pendampingan dilakukan saat pelaksanaan. Tim pelaksana terjun langsung melakukan pendampingan pada peserta bagaimana cara penggunaan kartu edukasi IUFD modifikasi Dwi Maryanti (IUFD MOBIDITI CARD) sehingga diharapkan saat dilakukan evaluasi semua peserta mampu melakukannya sendiri.

Pengabdian masyarakat dilaksanakan pada hari Selasa tanggal 21 Juli 2020 di Kelurahan Sidanegara Cilacap Tengah. Sasaran dalam pengabdian masyarakat ini adalah kader kesehatan ibu dan anak atau biasa disebut dengan Kader KIA. Kader KIA yang hadir dalam acara pengabdian masyarakat merupakan perwakilan dari 23 RW. Berdasarkan dari presensi kehadiran ditemukan dari $23 \mathrm{RW}$ terdapat $3 \mathrm{RW}$ yang tidak hadir, namun informasi dan IUFD MoBiDiti Card akan diteruskan oleh Kader KIA yang hadir langsung.

Tahap persiapan tim melakukan proses pengurusan surat ijin ke Kesbangpolinmas dan Bapelitbangda secara online. Dilanjutkan dengan kontrak waktu dengan ketua petugas lapangan KB selaku kordinator Kader KIA Kelurahan Sidanegara untuk mendapatkan waktu pelaksanaan pengabdian masyarakat. Menyiapkan lembar kuesioner, lembar presensi, materi dan media edukasi.

Tahap pelaksanaan dimulai dengan persiapan tempat oleh tim dan berbagi tugas untuk petugas presensi, petugas yang membagi dan menarik kembali kuesioner, serta berbagi materi untuk disampaikan ke sasaran. Pelaksanaan pertemuan Kader KIA ini berlangsung luring dengan tetap memperhatikan protokol kesehatan. Prosedur diterapkan ke semua yang hadir di aula adalah pengukuran suhu badan, cuci tangan dan pengunaan masker serta menjaga jarak duduk antar Kader KIA. Kader KIA mengisi presensi sebanyak 1x pada saat hadir.
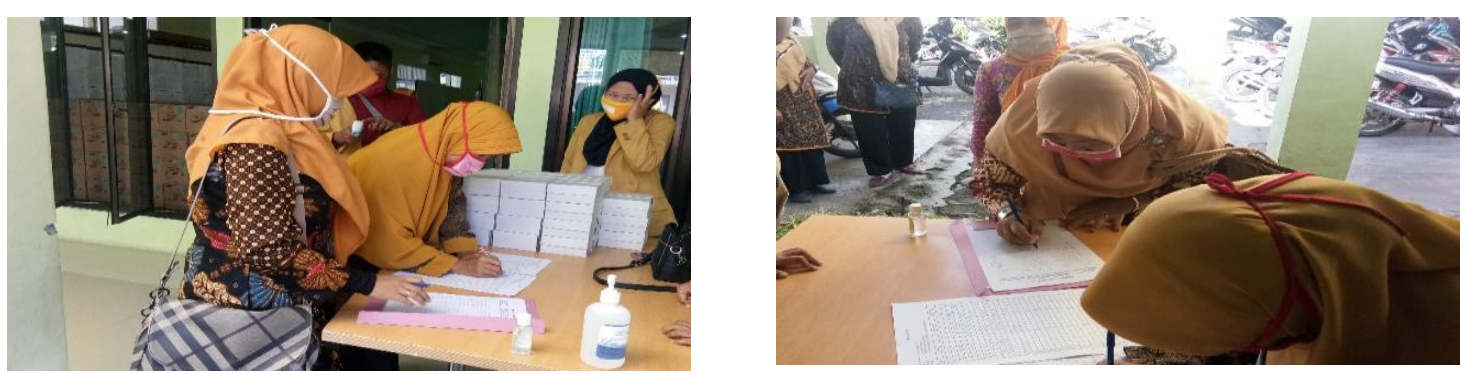

Gambar 1 Kader KIA Mengisi Presensi. 
Sebelum penyuluhan tentang KJDR, seluruh Kader KIA yang hadir diberikan pre tes dan telah diisi oleh 27 Kader KIA. Lembar kuesioner pre tes dan post test untuk mengkaji pengetahuan kader KIA sebelum dan sesudah penyuluhan menggunakan IUFD MoBiDiti Card. Pada saat post tes lembar kuesioner hanya terisi oleh 21 kader KIA saja, dikarenakan 6 Kader KIA lainnya ada kepentingan sehingga harus meninggalkan acara lebih awal. Oleh karena itu data diolah hanya 21 kader KIA saja.
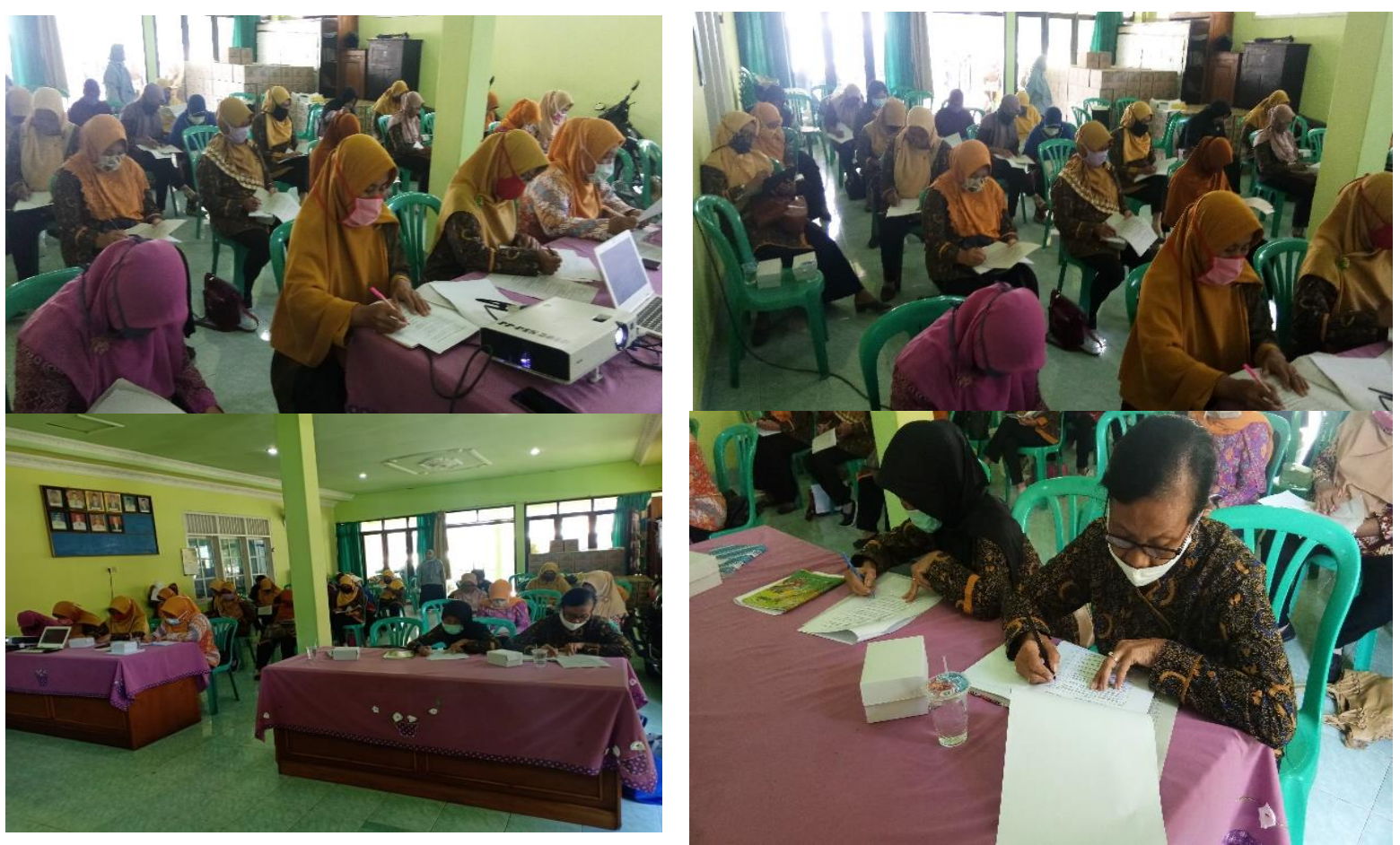

Gambar 2. Sesi penyampaian Materi

Pemberian materi diberikan kurang lebih dalam waktu 45 menit dilanjutkan tanya jawab selama 15 menit. Masing-masing tim memegang peran dalam pemberian materi. Pembicara satu memberikan materi tentang definisi dan kejadian dari kematian perinatal, pembicara 2 tentang KJDR dan pembicara tentang penggunaan IUFD MoBiDiti Card.
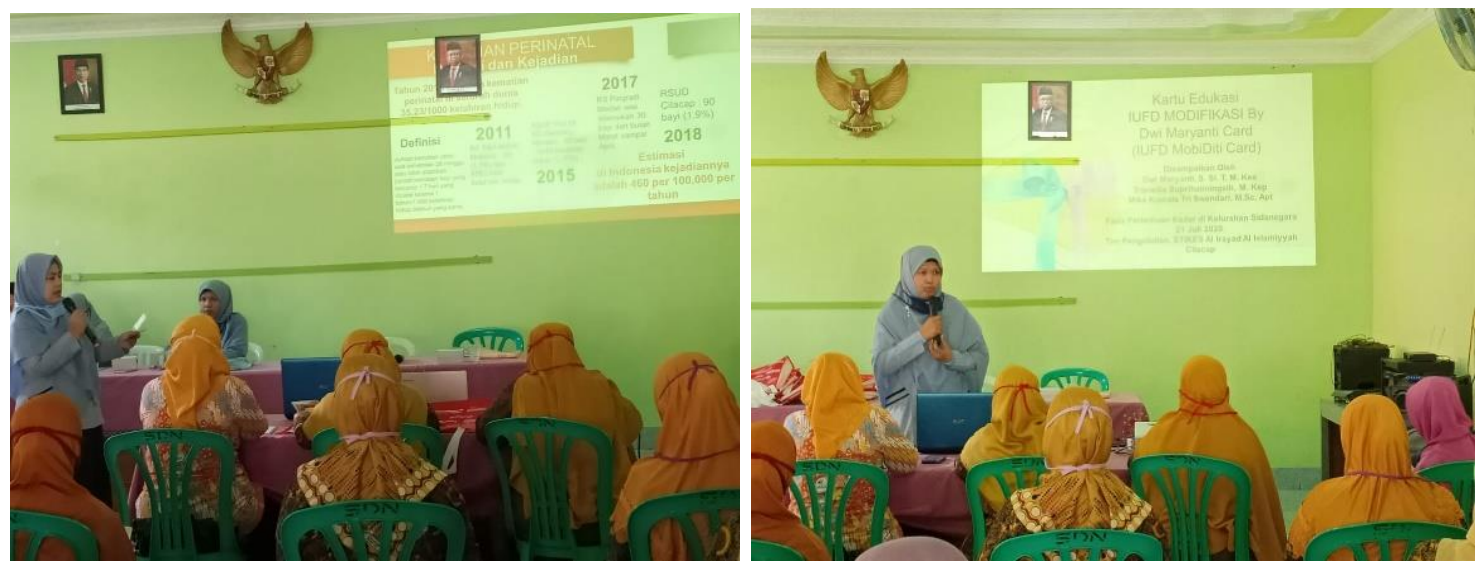

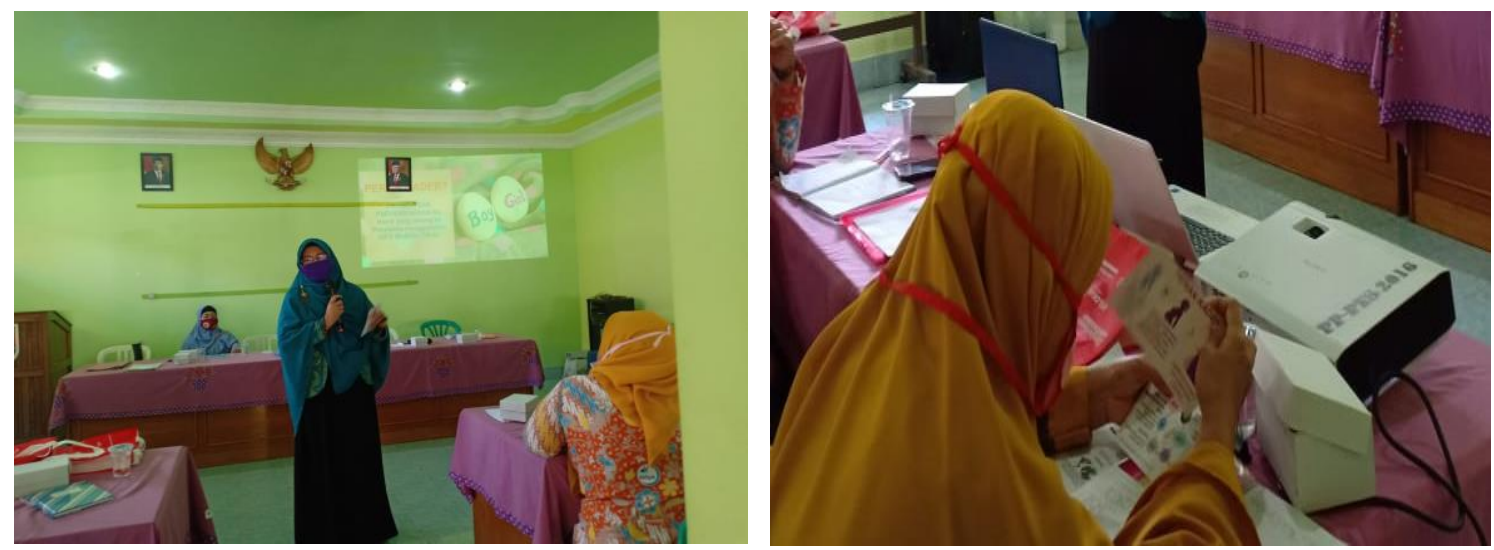

Gambar 3 Tim Pengabdian Masyarakat memberi penyuluhan

\section{HASIL DAN PEMBAHASAN}

1) Hasil

a. Karakteristik Kader KIA

a) Usia

Berdasarkan gambar 4 tampak bahwa usia kader KIA paling muda adalah 37 tahun dan paling tua 62 tahun dengan rata-rata usia kader KIA adalah 49 tahun.

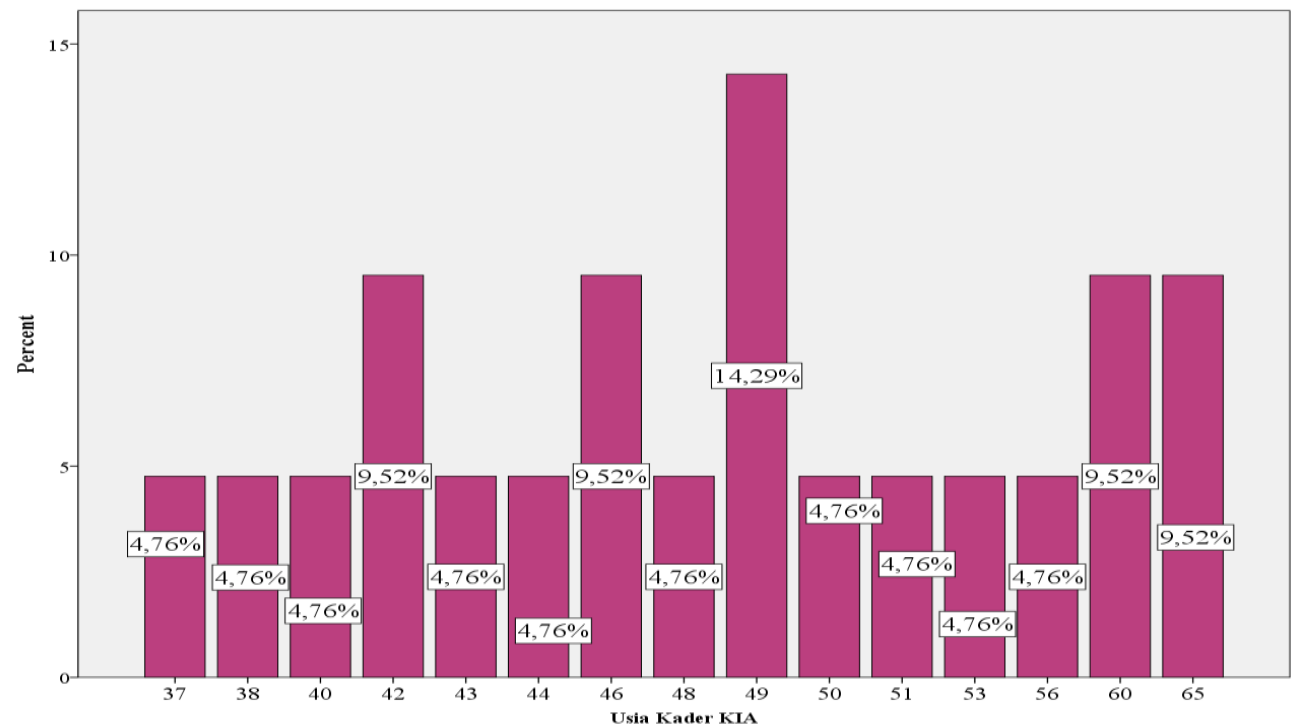

Gambar 4 Prosentase Usia Kader KIA

b) Pendidikan

Berdasarkan latar belakang pendidikan formal, diketahui bahwa mayoritas kader KIA merupakan lulusan SMA atau sederajat sejumlah 71,4\%. 


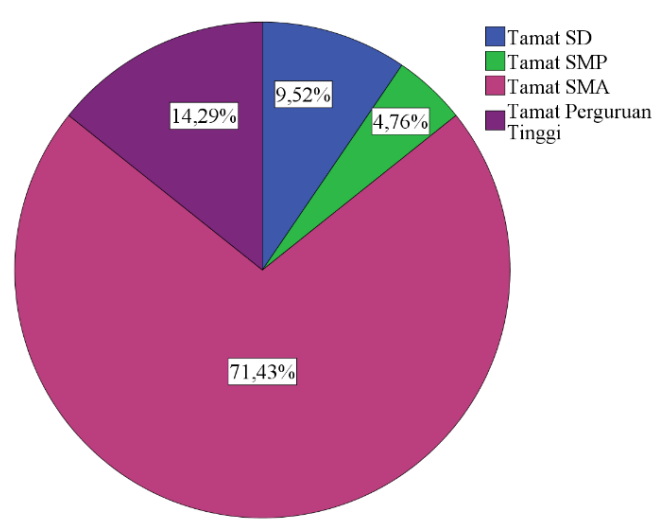

Gambar 5 Prosentase Pendidikan Kader KIA

\section{c) Lama menjadi Kader}

Kader KIA yang hadir di acara pengabdian masyarakat adalah kader KIA dengan pengalaman menjadi kader KIA minimal menjadi kader pada tahun pertama dan paling lama selama 30 tahun. Rata-rata kader KIA telah menjadi kader selama 7 tahun.

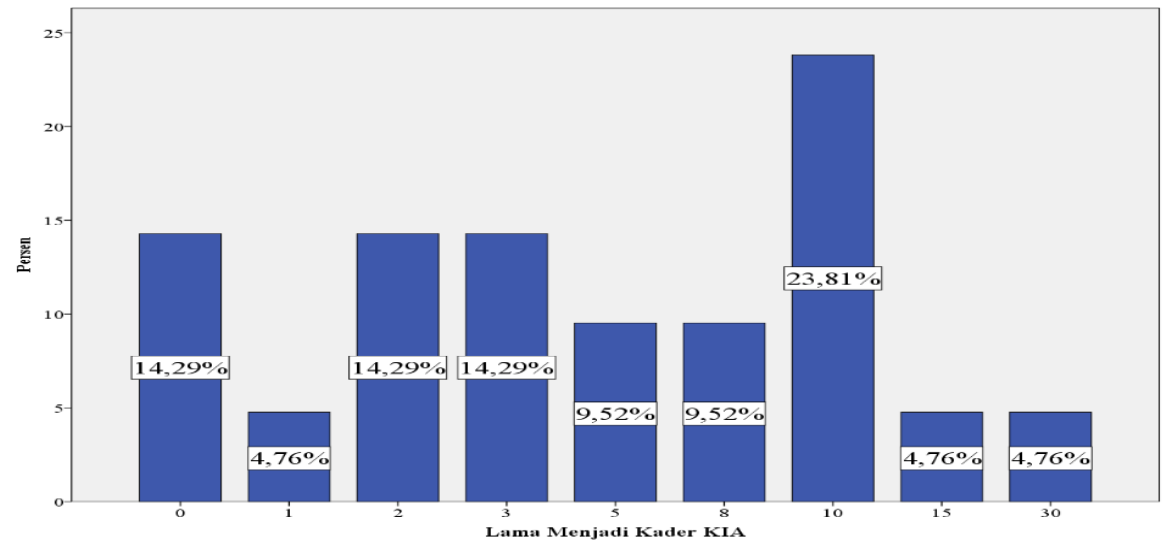

Gambar 6 Prosentase Lama Menjadi Kader KIA

d) Mendapat Informasi KJDR

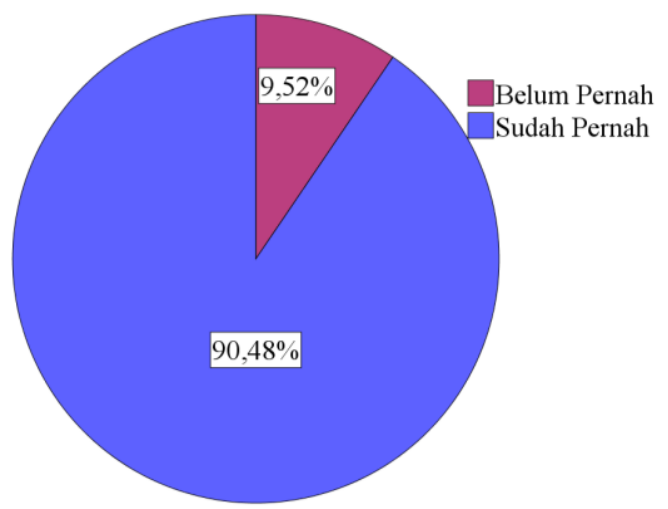

Gambar 7 Prosentase Mendapat Informasi KJDR 
Kader KIA menyatakan mayoritas belum pernah mendapatkan informasi tentang KJDR, diketahui hanya 2 Kader KIA saja yang menyatakan telah mendapat informasi KJDR sebelumnya.

e) Pekerjaan

Berdasarkan jenis pekerjaan, 100\% Kader KIA adalah ibu rumah tangga. Pekerjaan sebagai ibu rumah tangga tidak terikat jam dinas kantor, bila dilihat dari mayoritas usia kader KIA kemungkinan mayoritas adalah pensiunan.

b. Hasil Pre dan Post Tes

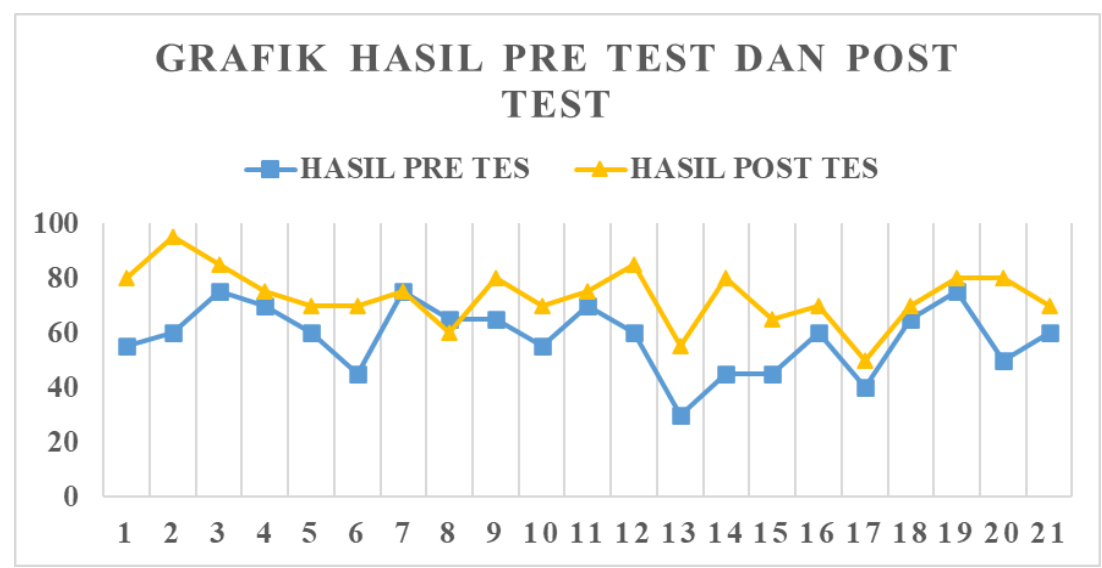

Gambar 8 Grafik Hasil Pre Tes dan Post Test

Hasil pre test diketahui rata-rata nilai kader KIA adalah 58 dan rata-rata post test adalah 73. Tampak pada gambar 8 bahwa grafik hasil post test berada diatas garis pre test, sehingga dapat diartikan terjadi peningkatan pengetahuan tentang KJDR sebelum dan sesudah pemberian penyuluhan.

\section{2) Pembahasan}

Media yang digunakan dalam pengabdian masyarakat adalah IUFD MoBiDiti Card. Penggunaan kartu edukasi sebagai media penyuluhan efektif dalam peningkatan pengetahuan (Fadhilah, Hartini, \& Alit Gunawan, 2017; Fadillah et al., 2017). Bila dilihat pada gambar 8 garis grafik post test diatas garis grafik pre test. Keberhasilan terjadinya peningkatan pengetahuan KJDR pada Kader KIA dapat disebabkan karena media yang digunakan bergambar, berwarna dan hanya berisi point-point penting sehingga mudah dipahami. Peningkatan pengetahuan kader disebabkan media kartu, didukung oleh penelitian dari Fibriana (2016) yang menunjukkan hasil bahwa penggunaan kartu berjodoh meningkatkan pengetahuan sebanyak $78,94 \%$. 
Keberhasilan meningkatkan pengetahuan Kader KIA tidak lepas dari karakteristik kader yang mayoritas lulusan SMA atau sederajat dan rata-rata telah menjadi kader selama 7 tahun. Latar belakang pendidikan dan pengalaman menjadi Kader KIA memungkinkan Kader KIA mudah menyerap informasi KJDR. Kader KIA setiap bulan rutin dikumpulkan untuk mendapat materi kesehatan, sehingga dimungkinkan sudah familier dengan istilah-istilah bidang kesehatan. Riset membuktikan bahwa tingkat pendidikan berpengaruh terhadap pengetahuan, demikian pula program-program penyuluhan berpengaruh terhadap peningkatan pengetahuan (Fangidae, 2016; Nydia Rena Benita, Julian Dewantiningrum, 2012; Pradono \& Sulistyowati, 2014)

Kartu IUFD MoBiDiti Card ini dibagikan dalam 23 paket untuk 23 RW dan telah diajarkan cara penggunaannya sebagai media penyuluhan kader untuk ibu hamil yang datang ke posyandu. Kelebihan IUFD MoBiDiti Card adalah selain desain yang menarik, mudah pula cara menggunakannya. Kader KIA dapat memulai dari kartu mana saja dan tidak harus berurutan, karena IUFD MoBiDiti Card didesain untuk mudah dijelaskan sesuai kebutuhan ibu hamil.

\section{KESIMPULAN DAN SARAN}

Berdasarkan hasil dan pembahasan diatas, dapat disimpulkan pemberian penyuluhan tentang KJDR menggunakan media IUFD MoBiDiti Card secara nyata dapat meningkatkan pengetahuan berdasarkan rerata peningkatan nilai hasil pre tes dan post tes.

Saran untuk kader KIA agar kartu IUFD MoBiDiti Card dapat benar-benar digunakan dalam menyuluh ibu hamil yang datang ke posyandu sehingga antisipasi KJDR dapat dilakukan sejak awal dan besar harapan angka kematian perinatal pun dapat menurun.

\section{DAFTAR PUSTAKA}

Cynthia, PH, Fatimah, SP, Rahfiludin, M. (2017). Faktor - Faktor Yang Berhubungan Dengan Kejadian Berat Badan Lahir Rendah (BBLR) Di Kabupaten Kudus (Studi di Wilayah Kerja Pu. Retrieved September 23, 2019, from Jurnal Kesehatan Masyarakat website:

https://webcache.googleusercontent.com/search?q=cache:cpp4MvQHK8sJ:https://media. neliti.com/media/publications/138032-ID-faktor-faktor-yang-berhubungan-denganke.pdf $+\& c d=9 \& h l=i d \& c t=\operatorname{lnk} \& g l=i d$

Fadhilah, D., Hartini, T. N. S., \& Alit Gunawan, I. M. (2017). Efektifitas Penyuluhan tentang Sayuran Menggunakan Media "Kartu Sayuran" terhadap Peningkatan Pengetahuan Siswa Sekolah Dasar. JURNAL NUTRISIA, 19(2), 100-105. https://doi.org/10.29238/jnutri.v19i2.18 
Fadillah, F., Tahlil, T., Keperawatan, M., Pascasarjana, P., Kuala, U. S., Aceh, B., ... Aceh, B. (2017). Efektivitas Kartu Kuartet Berbasis Multimedia Terhadap Perubahan Perilaku Hidup Bersih dan Sehat Berdasarkan Teori Health Promotion Model. Jurnal Ilmu Keperawatan, 5(1), 90-101.

Fajriana, A, Buanasita, A. (2018). Faktor Risiko Yang Berhubungan Dengan Kejadian Bayi Berat Lahir Rendah Di Kecamatan Semampir Surabaya. Retrieved September 23, 2019, from Media Gizi Indonesia website: https://webcache.googleusercontent.com/search?q=cache:Q9bGBCDmmr0J:https://ejournal.unair.ac.id/MGI/article/download/6062/5188+\&cd=12\&hl=id\&ct=clnk\&gl=id

Fangidae, H. (2016). Pengaruh Pendidikan Kesehatan terhadap Tingkat Pengetahuan dan Sikap Ibu Tentang Imunisasi di Puskesmas Pembantu Batuplat - Neliti. Retrieved August 23, 2020, from https://www.neliti.com/id/publications/316298/pengaruh-pendidikankesehatan-terhadap-tingkat-pengetahuan-dan-sikap-ibu-tentang

Fibriana, A. (2016). Efektifitas Penggunaan Media Kartu Berjodoh Dalam Meningkatkan Pengetahuan Ibu Tentang Pneumonia. JHE. Retrieved November 24, 2020, from https://journal.unnes.ac.id/sju/index.php/jhealthedu/article/view/18791

Marlenywati, Hariyadi, Didik, Ichtiyati, F. (2015). Faktor-Faktor Yang Mempengaruhi Kejadian BBLR DI RSUD DR. Soedarso Pontianak. Retrieved September 23, 2019, from Jurnal Vokasi Kesehatan website: http://webcache.googleusercontent.com/search?q=cache:EIlBbplLO4MJ:ejournal.poltek kespontianak.ac.id/index.php/JVK/article/download/31/25+\&cd=6\&hl=id\&ct=clnk\&gl=id

Maryanti, D. (2019). Faktor Risiko Maternal Neonatal Pada Intra Uterine Fetal Death (IUFD) Di RSUD Cilacap Tahun 2017 - 2018. Retrieved March 16, 2020, from STIKES Al Irsyad Al Islamiyyah Cllacap website: http://prosiding.stikesalirsyadclp.ac.id/2019/11/14/seminar-nasional-interprofessionaleducation-ipe-2019-peluang-dan-tantangan-perawat-bidan-dan-farmasi-sesuai-standarinternasional-di-era-industri-4-0/

Nydia Rena Benita, Julian Dewantiningrum, N. M. (2012). Pengaruh Penyuluhan Terhadap Tingkat Pengetahuan Kesehatan Reproduksi Pada Remaja Siswa SMP Kristen Gergaji Neliti. Retrieved August 23, 2020, from https://www.neliti.com/id/publications/106293/pengaruh-penyuluhan-terhadap-tingkatpengetahuan-kesehatan-reproduksi-pada-remaj

Pradono, J., \& Sulistyowati, N. (2014). Hubungan Antara Tingkat Pendidikan, Pengetahuan Tentang Kesehatan Lingkungan, Perilaku Hidup Sehat Dengan Status Kesehatan (Studi Korelasi Pada Penduduk Umur 10-24 Tahun di Jakarta Pusat). Buletin Penelitian Sistem Kesehatan, 17(1), 89-95. https://doi.org/10.22435/bpsk.v17i1 Jan.3579

Septiyaningsih, R., Indratmoko, S., \& Yunadi, F. D. (2019). Identifikasi Faktor Risiko Kejadian Anemia Pada Ibu Hamil Di Wilayah Kerja Puskesmas Cilacap Tengah I Tahun 2019. In Jurnal Kesehatan Ibu dan Anak Akademi Kebidanan An-Nur (Vol. 4).

Sofia semian*, Yani Widyastuti, \& Dyah Noviawati Setya Arum. (2018). Faktor-Faktor Yang Mempengaruhi Kejadian IUFD Di Kabupaten Manggarai Barat TAHUN 2015. Retrieved from http://eprints.poltekkesjogja.ac.id/1722/ 
Sulistyorinim D, Siswoyo, D. (2014). Analisis Faktor-Faktor Yang Mempengaruhi Kejadian BBLR Di Puskesmas Perkotaan Kabupaten Banjarnegara Dewie Sulistyorini1), Shint. Retrieved September 23, 2019, from Jurnal UNIMUS website: https://webcache.googleusercontent.com/search?q=cache:ivzm1LFDZ5UJ:https://jurnal. unimus.ac.id/index.php/psn12012010/article/download/1197/1250+\&cd=5\&hl=id\&ct=cl $\mathrm{nk} \& \mathrm{gl}=\mathrm{id}$

Triana, A. (2012). Pengaruh Kadar Hb dan Paritas dengan Kejadian Intra Uterine Fetal Death (IUFD) di RSUD Arifin Achmad Pekanbaru. Jurnal Kesehatan Komunitas, 2(1), 20-25. https://doi.org/10.25311/jkk.Vol2.Iss1.37 